УДК 378:796 - 051]:378.091.26

DOI:

Сергій Карасєвич, кандидат педагогічних наук, викладач кафедри спортивних дисциилін Уманського державного педагогічного університету імені Павла Тичини

\title{
МОНТТОРНГ ГОТОВНОСТІ МАЙБУТНІХ УЧИТЕЛІВ ФІЗИЧНОЇ КУЛЬТУРИ ДО ФІЗКУЛЬТУРНО-СПОРТИВНОЇ РОБОТИ У ЗАГАЛЬНООСВІТНІХ НАВЧАЛЬНИХ ЗАКЛАДАХ
}

У статті висвітлено моніторинг готовності майбутніх учителів фізичної культури до фізкультурно-спортивної роботи у загальноосвітніх навчальних закладах на основі аналізу програм фахових дисциплін та діагностики стану їх підготовки. Виявлено відсутність єдиної науково обтрунтованої системи формування професійних фізкультурно-спортивних знань і умінь, якими необхідно озброювати майбутнього вчителя фізичної культури. Встановлено відповідні причини. Здійснено діагностику підготовки майбутніх учителів фізичної культури до фізкультурно-спортивної роботи у загальноосвітніх навчальних закладах, яка показала недостатню готовність вчителів фізичної культури до цього виду діяльності, незнання свойх функцій в галузі фізкультурно-спортивної роботи, недостатню методичну та практичну готовність до організації та проведення фізкультурно-спортивної роботи з учнями тощо.

Ключові слова: моніторинг готовності майбутніх учителів фізичної культури; фізкультурноспортивна робота;діагностика підготовки майбутніх учителів фізичної культури; учителі фізичної культури.

Jim. 12.

Serhiy Karasyevych, Ph. D.(Pedagogy), Lecturer of the Sports Disciplines Department Uman Pavlo Tychyna State Pedagogical University

\section{MONITORING OF READINESS OF FUTURE TEACHERS OF PHYSICAL CULTURE TO PHYSICAL EDUCATION AND SPORTS WORK IN SECONDARY SCHOOLS}

The article reveals that the preparation of future teachers of physical culture for professional work should be carried out not only on the general cultural, psychological-pedagogical, and methodological levels, but include other types of preparation, including the physical, technical, athletic, etc., using the various modalities: classroom, extracurricular, independent. Monitoring of the readiness of future teachers of physical culture to physical education and sports work in secondary schools based on the analysis of programs of professional disciplines and diagnostics of a condition of their training. The absence of the unified science-based system of formation of professional physical culture and sports knowledge and skills, which should equip the future teacher of physical culture.

To identify the status of sports activity in secondary schools, where the future teachers of physical culture have to work, a survey of students was conducted in order to establish their level of physical activity and health, the knowledge of ways of preserving and promoting health, the forms of sports activity. There was found, that the work of teachers of physical education concerning the training of adolescents to use the exercise of sport character, as well as to create a positive focus on physical culture and sports classes in their free time, is not enough. The survey of teachers was conducted to identify the problems of physical culture and sports work; preparedness and holding of mass sports events. It is established that the reasons that constrain the use of physical-sports work in the educational process of secondary schools, on our opinion, are the economic, organizational and motivational. The article highlights the lack of a single scientifically well-founded system of formation of professional physical culture and sports knowledge and skills, which should equip the future teacher of physical culture. The appropriate reasons are described in the article. The diagnostics of training of future teachers of physical culture to physical education and sports work in secondary schools, which showed a lack of willingness of teachers of physical education to this activity, ignorance of its functions in the field of physical and sports activities, a lack of methodical and practical readiness to the organization and conduction of physical culture and sports work with students and the others.

Keywords: monitoring of readiness of future teachers of physical culture; sports and athletic performance; diagnosis of training of future teachers of physical culture; the teachers of physical culture.

П остановка проблеми. Оновлення всіх сторін суспільного життя висунуло принципово нові вимоги до особистості фахівця. На перший план виходить потреба суспільства в конкурентоспроможних спеціалістах, які здатні вирішувати складні професійні завдання в постійно мінливих умовах виробництва. Це обумовлює необхідність докорінних перетворень системи підготовки професійних кадрів, необхідність впровадження в системі вищої професійної освіти міжнародних стандартів. 


\section{МОНІТОРИНГ ГОТОВНОСТІ МАЙБУТНІХ УЧИТЕЛІВ ФІЗИЧНОЇ КУЛЬТУРИ ДО ФІЗКУЛЬТУРНО-СПОРТИВНОӤ РОБОТИ У ЗАГАЛЬНООСВІТНІХ НАВЧАЛЬНИХ ЗАКЛАДАХ}

В умовах постійних змін, спрямованості вектора вищої освіти на євроінтеграцію зростають вимоги до підготовки майбутніх учителів фізичної культури, найважливішим напрямом роботи якого $\epsilon$ максимально повне урахування тих соціальних i професійних умов, в яких вони будуть жити i працювати.

Проблемам професійної підготовки майбутніх учителів фізичної культури присвячені праці вітчизняних і зарубіжних науковців (Е. Вільчковський, Л. Демінська, Н. Денисенко, В. Дрюков, А. Дубенчук, С. Єрмаков, В. Заклюжний, Т. Іванова, Р. Маслюк, С. Мединський, С. Омельченко, В. Омельяненко, В. Платонов, Н. Самсутіна, Д. Солопчук, Л. Сущенко, С. Чещейко та ін.). Дослідники солідарні в тому, що в сучасних умовах необхідні серйозні перетворення в галузі підготовки майбутніх учителів фізичної культури.

Ряд авторів (О. Ажиппо [1], О. Артемович [2], I. Гільова [3], Є. Захаріна [5], Б. Максимчук [7], О. Онопрієнко [9], А. Сущенко [10], О. Тимошенко [11], Б. Шиян [12]) розглядають підготовку майбутніх вчителів фізичної культури до професійної діяльності за трьома напрямами: загальнокультурному, психолого-педагогічному та методичному.

Загальнокультурна підготовка сприяє формуванню всебічно розвиненої і соціальноактивної особистості майбутнього вчителя фізичної культури, компетентного в питаннях наукової, філософської, біологічної картин світу, місця людини в цьому світі. Здійснення загальнокультурної підготовки відбувається в процесі вивчення таких навчальних дисциплін: “Історія та культура України”, “Філософія”, “Іноземна мова”, “Анатомія людини”, “Фізіологія людини”, "Вікова фізіологія та шкільна гігієна" тощо та в процесі активної участі у позааудиторних заходах (наукові конференції, наукові проблемні групи, гуртки тощо).

Психолого-педагогічна підготовка дозволяє озброїти майбутніх вчителів знаннями про закономірності і принципи освітньо-виховного процесу та вміннями використовувати їх у педагогічній діяльності. Цей вид підготовки реалізується в процесі вивчення навчальних дисциплін "Педагогіка", "Психологія" та ін.; у процесі підготовки доповідей до семінарських занять, написанні рефератів, в самостійній роботі і при проходженні педагогічної практики в загальноосвітніх навчальних закладах.

Методична підготовка передбачає створення необхідних умов для засвоєння майбутніми педагогами системи знань щодо здійснення певних видів роботи у загальноосвітніх навчальних закладах, зокрема й фізкультурноспортивної, а також оволодіння конкретними прийомами, методами і формами роботи в галузі фізичного виховання школярів, навичками вирішення педагогічних проблем при плануванні, організації і проведенні цих видів роботи. Здійснюється під час занять $з$ дисципліни ”Теорія і методика фізичного виховання" та базових фізкультурно-спортивних видів: “Легка атлетика з методикою навчання”, “Гімнастика з методикою навчання", "Спортивні ігри 3 методикою навчання”, "Рухливі ігри з методикою навчання”, “Лижний спорт 3 методикою навчання”, “Плавання $з$ методикою навчання" та ін., в ході науково-дослідної роботи (написання рефератів і підготовки доповідей) і при проходженні педагогічної практики в загальноосвітніх навчальних закладах.

В. Дрюков, В. Платонов виокремлюють спортивну, фізичну, технічну, тактичну, психологічну підготовки, кожна 3 яких характеризується самостійними ознаками [4; 8].

Фізична підготовка спрямована на розвиток i вдосконалення основних рухових якостей (сили, швидкості, гнучкості, спритності, витривалості), що $є$ одним 3 основних резервів підвищення спортивних досягнень. Оптимізація технічної підготовки здійснюється 3 урахуванням тілобудови, функціональних даних, особливостей вищої нервової діяльності особистості, що визначають основні рухові моделі виду спорту, властиві лише цій людині. Тактична підготовка - уміння провести спортивну боротьбу для завоювання перемоги. Тактична підготовка містить у собі вивчення можливостей суперника й умов майбутніх змагань, освоєння тактичних прийомів та їх варіантів, уміння скласти і реалізувати план спортивної боротьби, спроможності уважно спостерігати, швидко сприймати й оцінювати ситуацію і вчасно приймати правильні рішення. Психологічна підготовка - одне з найважливіших завдань у фізкультурно-спортивному процесі, що передбачає розвиток специфічних якостей: сили волі, швидкості рухових реакцій, сміливості, рішучості, наполегливості, кмітливості, емоційної стійкості.

Отже, підготовка майбутніх учителів фізичної культури до професійної діяльності має здійснюватися не тільки на загальнокультурному, психолого-педагогічному, методичному рівнях, а й включати інші види підготовки, зокрема фізичну, технічну, спортивну тощо. Усі види підготовки здійснюються при використанні різних форм роботи: аудиторної, позааудиторної, самостійної. 


\section{МОНТТОРИНГ ГОТОВНОСТІ МАЙБУТНІХ УЧИТЕЛІВ ФІЗИЧНОЇ КУЛЬТУРИ ДО ФІЗКУЛЬТУРНО-СПОРТИВНОЇ РОБОТИ У ЗАГАЛЬНООСВІТНІХ НАВЧАЛЬНИХ ЗАКЛАДАХ}

Р. Маслюк виділяє три основні форми фізкультурної діяльності студентів: перша форма, яка реалізується на академічних заняттях у навчальний час, передбачає комплексне вирішення трьох груп педагогічних завдань: освітніх, виховних і оздоровлювальних із домінівною освітньою спрямованістю; друга форма передбачає активні заняття спортом у позааудиторний час, максимальний розвиток рухових здібностей, що забезпечують досягнення високих рівнів спортивно-технічної майстерності студентів, є пріоритетним напрямом спільної реалізації виховних і освітніх завдань; третя форма - активне дозвілля студентів - передбачає організацію самостійних занять у позааудиторній роботі, використання різних форм і засобів фізичної культури $[6,75]$.

Аналіз вищезазначених напрямів підготовки майбутніх вчителів фізичної культури покладено в основу моніторинг готовності майбутніх учителів фізичної культури до фізкультурноспортивної роботи у загальноосвітніх навчальних закладах.

Мета статті - здійснити моніторинг готовності майбутніх учителів фізичної культури до фізкультурно-спортивної роботи у загальноосвітніх навчальних закладах на основі аналізу програм фахових дисциплін та діагностики стану їх підготовки.

Результати дослідження. Підготовка студентів до реалізації фізкультурно-спортивної діяльності передбачає цілеспрямоване засвоєння змісту дисципліни “Теорія і методика фізичного виховання" та дисциплін базових фізкультурноспортивних видів: “Легкої атлетики з методикою навчання”, “Гімнастики з методикою навчання”, “Спортивних ігор з методикою навчання", "Рухливих ігор з методикою навчання”, “Лижного спорту з методикою навчання”, “Плавання 3 методикою навчання" та ін.

Виклад основного матеріалу. Навчальний матеріал кожної дисципліни диференційований через традиційні розділи та підрозділи: теоретичний, практичний (методико-практичний і навчально-тренувальний) і контрольний:

- теоретичний передбачає оволодіння студентами системою науково-практичних $\mathrm{i}$ спеціальних знань 3 фізичної культури;

- практичний, складається 3 двох підрозділів: a) навчально-тренувального, який орієнтує на широке використання теоретичних знань, методичних умінь і різноманітних засобів фізичної культури, спортивної та професійно-прикладної фізичної підготовки студентів для набуття індивідуального і колективного практичного досвіду фізкультурно-спортивної діяльності; б) методико-практичного, що забезпечує оволодіння методами і способами практичного використання знань, умінь і навичок фізкультурно-спортивної роботи в професійній діяльності;

- контрольний, що визначає диференційований об'єктивний результат теоретичної та практичної діяльності студентів.

Аналіз навчальних програм довів, що в них має місце дублювання матеріалу, що, в свою чергу, є нераціональною координацією дисциплін базових фізкультурно-спортивних видів і навчальної дисципліни “Теорія і методика фізичного виховання".

Отже, аналіз чинних програм 3 фахових дисциплін виявив відсутність єдиної науково обгрунтованої системи формування професійних фізкультурно-спортивних знань і умінь, якими необхідно озброювати майбутнього вчителя фізичної культури.

У чинних програмах не сконцентровано питання обсягу і змісту фізкультурно-спортивних знань і умінь, послідовність їх формування 3 окремих дисциплін та семестрів. У результаті студенти не опановують багатьма професійними знаннями, вміннями і навичками в їх майбутній педагогічній діяльності.

Для виявлення стану фізкультурно-спортивної діяльності у загальноосвітніх навчальних закладах, в якій доведеться працювати майбутньому вчителю фізичної культури, проведено опитування учнів 3 метою встановлення рівня їх рухової активності та стану здоров'я, виявлення знань про засоби збереження і зміцнення здоров'я, форми фізкультурно-спортивної діяльності. В анкетуванні взяли участь 134 учні 6-11 класів 13 загальноосвітніх навчальних закладів.

Аналіз даних щодо виявлення у школярів знань про важливість засобів збереження і зміцнення здоров'я дозволив встановити, що $67,4 \%$ респондентів вважають актуальним правильне харчування, 71,6 \% регулярні заняття фізичними вправами, 54,8 \% підтримання чистоти тіла, $60,5 \%$ відмову від шкідливих звичок і перебування на свіжому повітрі. Однак такі вагомі чинники, як загартовування, дотримання режиму дня і виконання ранкової гімнастики не знайшли належного відображення в структурі знань школярів, їх відзначили тільки 19,6 \%. Це вказує на недоліки в їх освітній підготовці щодо практичного використання засобів фізичної культури для підтримки здоров'я. Про це свідчить і те, що 47,8 \% респондентів не роблять ранкову гімнастику, 47,3 \% іноді виконують, але дуже рідко і тільки 4,9 \% роблять це систематично. 


\section{МОНІТОРИНГ ГОТОВНОСТІ МАЙБУТНІХ УЧИТЕЛІВ ФІЗИЧНОӤ КУЛЬТУРИ ДО ФІЗКУЛЬТУРНО-СПОРТИВНОЇ РОБОТИ У ЗАГАЛЬНООСВІТНІХ НАВЧАЛЬНИХ ЗАКЛАДАХ}

Найбільш привабливими формами занять фізичною культурою 47,7 \% опитаних школярів називають туристичні походи. Великий інтерес у дітей викликає гра 3 однолітками у дворі і на шкільній ділянці, спортивному майданчику $31,7 \%, 20,6$ \% школярів вважають за краще займатися в спортивних секціях. Періодично відвідують спортивні секції 38,7 \% школярів, $29,7 \%$ іноді, 31,6 \% школярів ніколи не відвідували жодної спортивної секції.

Отже, намітилася тенденція до зниження інтересу у дітей до традиційних форм фізичного виховання, а фізкультурно-спортивна діяльність, обмежена тільки рамками шкільної програми, не завжди викликає у них достатній інтерес. Водночас, форми фізичної активності, засновані на інтересах школярів, переважно оздоровчорозважальної спрямованості користуються у них великою популярністю.

На питання, "Які фізкультурно-спортивні заходи проводяться у вашому загальноосвітньому навчальному закладі в режимі навчального дня?", 3,6 \% школярів відзначають, що це гімнастика до занять, 7,3 \% фізкультурні паузи і хвилинки на уроках, 21,7 \% респондентів відзначають організоване використання в загальноосвітніх навчальних закладах різних форм фізичної активності на перервах, наявність спортивних годин виділяють 8,5 \% підлітків. Взагалі, жодні фізкультурно-спортивні заходи в режимі навчального дня загальноосвітніх навчальних закладів не проводяться в 58,9 \% випадків.

Докладно вивчався стан справ, пов'язаних 3 проведенням ігор і фізичних вправ в паузах між уроками, і стан самостійних занять фізичними вправами підлітків 3 фізкультурно-спортивною спрямованістю. Аналіз результатів анкетування показує, що в 58,9 \% загальноосвітніх навчальних закладах взагалі не проводяться керовані рухливі перерви. Передбачене комплексною програмою обов'язкове щоденне включення в режим навчального дня ігор та фізичних вправ на перервах здійснюється на практиці лише в 1,2 \% загальноосвітніх навчальних закладах досліджуваних регіонів.

3'ясування ступеня самостійних занять фізичними вправами з фізкультурно-спортивною спрямованістю також свідчить про ㄲï незадовільний стан. Так, кожного дня самостійно займаються лише 16,8 \% хлопців і 3,2 \% дівчат, кілька разів на тиждень 19,8 \% хлопців і 8,8 \% дівчат, взагалі самостійно не займаються 28,9\% хлопців і 54,2 \% дівчат.

Незважаючи на недостатність організованих фізкультурно-спортивних заходів в загальноосвітніх навчальних закладах, 73,2 \% хлопців та 51,7 \% дівчат від загального числа опитаних відзначають, що із задоволенням беруть або брали б участь у різних розважальних видах фізкультурної діяльності 3 метою: можливості активно відпочити, отримати задоволення від занять 38,9 \% хлопців і 34,2 \% дівчат; спілкування 3 товаришами 29,9 \% хлопців і 19,3 \% дівчат; поправити здоров'я, поліпшити фізичний розвиток 14,6 \% хлопців; 25,1\% дівчат; виділитися, самоствердитися $10,4 \%$ хлопців і $5,5 \%$ дівчат; просто зайняти час $6,2 \%$ хлопців і 8,9 \% дівчат. Інші пріоритети вказали 7,0 \% дівчат.

Аналіз зазначених переваг дає підставу стверджувати, що в мотиваційній структурі фізкультурно-спортивної діяльності підлітків в загальноосвітніх навчальних закладах домінівними $\epsilon$ потреби в активному відпочинку, приємному використанні часу, переживанні позитивних емоцій в процесі рухових дій і взаємодій 3 партнерами. Крім того, досить значущими $є$ потреби в спілкуванні з однолітками, а також у фізичному самовдосконаленні. Потреба в самоствердженні (прагненні до суперництва) більшою мірою характерна для хлопців, ніж для дівчат.

Водночас 25,2 \% хлопців і 43,1 \% дівчат підтверджують свою неохочу участь (або неучасть зовсім) в організованих загальноосвітніх навчальних закладах заходах фізкультурноспортивної спрямованості.

Отримані в результаті обстеження підлітків фактичні дані показують, що загальноосвітнім навчальним закладом, зокрема, вчителями фізичної культури, недостатньо здійснюється робота 3 навчання підлітків застосуванню фізичних вправ спортивного характеру, а також 3 формування позитивної спрямованості на фізкультурно-спортивні заняття у вільний час.

За результатами анкетування учнів проведено опитування педагогів на предмет виявлення труднощів з фізкультурно-спортивної роботи; готовності до неї та проведенні масових спортивних заходів.

3 метою виявлення причин, що стримують впровадження фізкультурно-спортивних заходів в режим функціонування сучасних загальноосвітніх навчальних закладів, ми звернулися до думки вчителів. За даними опитування вчителів (69 чоловік), 34,8 \% респондентів вказали на недостатню сформованість у них уявлень про взаємозв'язок фізичної культури з іншими предметами, 11,6 \% на погану теоретичну підготовку, 8,7 \% слабке знання теорії та методики 
МОНІТОРИНГ ГОТОВНОСТІ МАЙБУТНІХ УЧИТЕЛІВ ФІЗИЧНОӤ КУЛЬТУРИ ДО ФІЗКУЛЬТУРНО-СПОРТИВНОӤ РОБОТИ У ЗАГАЛЬНООСВІТНІХ НАВЧАЛЬНИХ ЗАКЛАДАХ

фізичної культури, 13,0 \% недостатне знання методики навчання дітей руховим діям, 31,9 \% відсугність необхідної методичноїлітератури. Практично всі вчителі відзначають труднощі в організаційному відношенні, пов'язанізіслабкою матеріально-технічною базою загальноосвітніх установ.

Відповідаючи на питання: “Що потрібно для поліпшення якості професійної підготовки майбутніх вчителів фізичної культури”, 23,2 \% респондентів пропонують посилити теоретичну підготовку, 29,0 \% забезпечити проведення теоретичних і практичних занять з методичною спрямованістю, 15,9 \% організувати процес інтегрованого навчання, що об'єднує теоретичні знання 3 фізичної культури 3 іншими загальноосвітніми предметами, 18,8 \% включити в зміст навчальної практики розділу щодо організації фізкультурно-спортивної діяльності та зробити їі безперервною; 7,3 \% проводити методичні заняття фізкультурної спрямованості на базі загальноосвітніх установ різного типу, 5,8 \% використовувати нові технології в навчанні.

Діяльність педагогів оцінювалася нами за ступенем труднощів, які вони відчували при організації фізкультурно-спортивної роботи. Доведено, що у загальноосвітньому навчальному закладі переважає недооцінка значення фізичної культури, у вчителів практично відсутня мотивація участі в проведенні фізичного виховання за допомогою використання всього різноманіття форм фізкультурно-спортивної роботи з метою зміцнення і збереження здоров'я молодого покоління.

Результати анкетування свідчать про те, що багато вчителів загальноосвітніх навчальних закладів зазнають труднощів в організації та проведенні різних фізкультурно-спортивних заходів з фізичного виховання.

Головними причинами, що стримують використання фізкультурно-спортивних форм роботи в освітньому процесі загальноосвітніх навчальних закладів, на наш погляд $є$ економічні, організаційні та мотиваційні. Економічні причини пов'язані з недостатньо розвиненою матеріальнотехнічною базою загальноосвітніх навчальних закладів та їх кадровим забезпеченням. Організаційні 3 відсутністю програм, що розкривають усі теоретичні та методичні аспекти підготовки майбутніх учителів до фізкультурноспортивної діяльності в загальноосвітніх навчальних закладах. Мотиваційні причини викликані недооцінкою ролі фізкультурноспортивної діяльності в фізкультурній освіті школярів і необхідністю підготовки до неї майбутніх вчителів.
Отже, провідною перешкодою на шляху залучення учнів до систематичних занять фізкультурно-спортивною діяльністю в загальноосвітніх навчальних закладах $\epsilon$ недостатня спеціальна підготовка майбутніх учителів фізичної культури.

Для вивчення проблем підготовки майбутніх учителів фізичної культури у закладах вищої освіти проведено анкетування серед студентів 3 метою виділення провідних мотивів, які визначили вибір ними занять фізичною культурою та спортом. У анкетуванні взяли участь 139 осіб.

Серед отриманих відповідей на першому місці виявився мотив досягнень (“посісти перше місце в змаганнях", “бути хорошим спортсменом" тощо). Цей мотив був обраний усіма студентами. 28,4 \% студентів на перше місце поставили мотив здоров'я (“бути здоровою людиною”). Іншими мотивами визначено: 22,9 \% мотиви, засновані на почутті обов' язку і відповідальності (“'захищати слабких”); 21,1 \% мотиви, засновані на інтересах (інтерес до спорту, інтерес до особистості вчителятренера тощо); 18,4 \% мотиви, засновані на почутті страху; 9,2 \% мотиви, засновані на потребах особистості (важлива потреба в активному рухові).

Для нас важливим виявився висновок, що всі студенти, які займаються фізкультурноспортивною діяльністю, мають чітко сформовані мотиви цієї діяльності (на жаль, таких студентів тільки 12,5 \% 3 опитаних).

Нами проведено анкетування майбутніх учителів фізичної культури на предмет виявлення пріоритетних цінностей у фізкультурноспортивній діяльності. За нашими даними, виявилася стабільною така ієрархія цінностей: 1) щастя в особистому житті $(38,2 \%) ; 2)$ гарне здоров’я (18,9 \%); 3 ) хороші і вірні друзі (11,9 \%); 4) матеріальне благополуччя $(11,4 \%) ; 5)$ чиста совість $(8,4 \%) ; 6)$ цікава робота $(6,2 \%) ; 7)$ бути корисним людям (5,0\%) та інші відповіді. Крім того, студенти на одне 3 перших місць ставлять спілкування з іншими людьми як цінніснозначущу якість.

3 огляду на низьку мотивацію до активності в заняттях з фізичної культури, проведено аналіз стану здоров'я студентів педагогічного університету, який оцінювався за хронічними захворюваннями за окремий період часу. Дані, що відображають загальну захворюваність серед студентів, отримано на підставі аналізу медичних карт і результатів масових медичних оглядів, які проводилися на базі студентської поліклініки. На основі аналізу виявлено, що за останні кілька років спостерігається зниження рівня здоров'я студентів 


\section{МОНІТОРИНГ ГОТОВНОСТІ МАЙБУТНІХ УЧИТЕЛІВ ФІЗИЧНОЇ КУЛЬТУРИ ДО ФІЗКУЛЬТУРНО-СПОРТИВНОЇ РОБОТИ У ЗАГАЛЬНООСВІТНІХ НАВЧАЛЬНИХ ЗАКЛАДАХ}

(збільшується кількість студентів молодших курсів у спеціальних медичних груп та звільнених від занять фізичною культурою). У структурі захворюваності можна виділити найбільш істотні, 3 них: захворювання органів дихання 52,5\% (40,2 \% припадає на частку гострих респіраторних інфекцій); хвороби нервової системи та органів чуття $15,2 \%$; захворювання сечостатевої системи становлять $6,5 \%$; органів травлення 5,3\%; кістково-м'язевої системи 4,3\%; 16,2% інші.

Отримані результати свідчать про недостатню готовність майбутніх учителів до ведення фізкультурно-спортивної діяльності зі школярами пов'язаних зі слабким власним здоров'ям.

Важливим для нашого дослідження було питання якості підготовки майбутніх вчителів фізичної культури до фізкультурно-спортивної діяльності. На питання: “Які фізкультурноспортивні заходи Ви знаєте?” повних відповідей отримано не було; 60,4 \% респондентів дали частково правильні відповіді, $16,8 \%$ неправильні, інші студенти відмовилися від відповіді. Значна частина опитаних не можуть зв'язати проблеми здоров'я і фізичного виховання, проблеми індивідуальної фізичної культури і індивідуальних занять спортом. Відповідаючи на питання: “Наведіть приклади зв'язків спорту та фізичної культури” тільки 18,6 \% студентів виявили дійсно прямий зв'язок між відповідністю здоров'я та спорту.

Підтвердженням ефективності обраної нами стратегії дослідження $є$ думка студентів щодо розвитку студентського спорту в університеті. Усього було опитано 135 студентів (з них: другий курс 27 дівчат і 36 юнаків, третій курс 42 дівчини і 30 юнаків).

На підставі отриманих результатів, можна відзначити, що велике значення розвитку студентського спорту в університеті виявляють дівчата другого курсу (71,8 \%), в цілому середній рівень становить 65,2\%, незадоволені $13,3 \%$ студентів.

Вищевикладене ще раз підтверджує, що проблема мотивації і формування потреби у фізичному розвитку та самовдосконаленні $\epsilon$ актуальною, що пошуку нових шляхів ефективного впливу на мотиваційно-ціннісну сферу особистості студентів.

Найбільш значущими мотивами відвідування занять 3 дисциплін базових фізкультурноспортивних видів $\epsilon$ : “бажання підвищити фізичну підготовленість”, “необхідність отримання заліку”, “бажання бути здоровим” i “бажання вдосконалювати статуру”, 23,6 \% 3 числа опитаних дівчат та юнаків відвідують академічні заняття з примусу через необхідність отримання заліку.

Відповідаючи на запитання анкети "Чи знайомі Ви 3 формами організації позааудиторної спортивно-масової діяльності?" отримано 82,1% ствердних відповідей. 32,6 \% студентів вважають доступною формою заняття в спортивній секції ВН3, оскільки вони проходять в зручний час дозволяють займатися обраним видом спорту. Найбільш популярним видом фізкультурноспортивної діяльності серед студентів педагогічного ВНЗ $є$ волейбол, з опитаних його вибирають 21,7%. На другому місці популярності знаходиться важка атлетика, якій віддають перевагу $18 \%, 16 \%$ учасників анкетування вибрали шейпінг, $15 \%$ студентів баскетбол, також 14 \% обрали футбол, 10 \% вказали на легку атлетику, 5,3 \% лижний спорт.

Слід зазначити, що студенти в цілому позитивно ставляться до фізичної культури, але, досить високий відсоток байдужого ставлення до фізкультурно-спортивної діяльності. Рухова активність студентів досить низька не більше 2 годин вільного часу в тиждень. Результати дослідження свідчать про недостатнє значення у житті студентів фізичної культури і здорового способу життя, про низьку фізкультурну грамотність студентів.

Можемо констатувати, що причинами недостатньої підготовленості вчителів фізичної культури є незнання своїх функцій в галузі фізичного виховання школярів; слабка методична та практична готовність до організації та проведення фізкультурно-спортивної роботи 3 учнями; відсутність знань директивних документів з фізичного виховання дітей шкільного віку.

Висновки. Проведений моніторинг готовності майбутніх учителів фізичної культури до фізкультурно-спортивної роботи у загальноосвітніх навчальних закладах на основі аналізу програм фахових дисциплін виявив відсутність єдиної науково обгрунтованої системи формування професійних фізкультурно-спортивних знань і умінь, якими необхідно озброювати майбутнього вчителя фізичної культури. У чинних програмах не сконцентровані питання обсягу і змісту фізкультурно-спортивних знань і умінь, послідовність їх формування з окремих дисциплін та семестрів. У результаті студенти не отримують фахові знання, уміння і навички для подальшої професійної діяльності.

Діагностика процесу підготовки майбутніх учителів фізичної культури до фізкультурноспортивної роботи у загальноосвітніх навчальних 


\section{МОНІТОРИНГ ГОТОВНОСТІ МАЙБУТНІХ УЧИТЕЛІВ ФІЗИЧНОЇ КУЛЬТУРИ ДО ФІЗКУЛЬТУРНО-СПОРТИВНОӤ РОБОТИ У ЗАГАЛЬНООСВІТНІХ НАВЧАЛЬНИХ ЗАКЛАДАХ}

закладах показала недостатню готовність вчителів фізичної культури до цього виду діяльності, незнання своїх функцій в галузі фізкультурноспортивної роботи, недостатня методична та практична готовність до організації та проведення фізкультурно-спортивної роботи з учнями тощо.

\section{ЛІТЕРАТУРА}

1. Ажиппо О. Ю. Теоретико-методичні засади підготовки майбутніх учителів фізичної культури до професійної діяльності в загальноосвітніх навчальних закладах: дис. ... д-ра пед. наук. Харків, 2013. 485 c.

2. Артемович О. І. Вплив різних видів фізкультурноспортивних занять на рівень фізичного здоров'я підлітків. Сучасні проблеми фізичного виховання та спорту школярів і студентів України: IV всеукр. наук. студ. конф.: матеріали (Суми, 22-23 квіт. 2004 р.). Суми: СумДПУ, 2004. С. 178-183.

3. Гільова І. Впровадження інноваційних технологій та їх елементів на уроках фізичної культури. Фізичне виховання в школі. 2007. № 3. С. 22-24.

4. Дрюков В. О. Раціональність спортивної підготовки. Олімпійська арена. 2007. № 11. С. 6-8.

5. Захаріна Є. А. Професійна підготовка майбугніх учителів фізичної культури до позакласної та позашкільної оздоровчо-виховної роботи: теорія та методика: монографія. Запоріжжя: КПУ, 2012. 439 с.

6. Маслюк Р. В. Професійна підготовка майбутніх учителів фізичної культури в системі “педагогічний коледж - педагогічний університет”: дис. ... канд. пед. наук. Умань, 2015. 286 с.

7. Максимчук Б. А. Підготовка майбутніх учителів початкових класів до організації спортивно-масової роботи: дис. ... канд. пед. наук. Вінниця, 2007. 176 с.

8. Онопрієнко О. В. Формування базових професійних компетентностей майбутнього вчителя фізичної культури у процесі вивчення фахових дисциплін: автореф. дис. ... канд. пед. наук. Черкаси, 2009. $20 \mathrm{c}$.

9. Платонов В. Н. Система подготовки спортсменов в олимпийском спорте. Общая теория и её практические приложения. Киев: Олимпийская литература, 2004. 808 с.

10. Сущенко А. В. Розвиток педагогічної творчості майбутніх учителів фізичного виховання в ході педагогічної практики. Педагогіка формування творчої особистості у вищій і загальноосвітній школах. Запоріжжя. 2011. Вип. 19. С. 275-280.

11. Тимошенко О. В. Оптимізація професійної підготовки майбутніх вчителів фізичної культури: монографія. Київ: НПУ ім. М. П. Драгоманова, 2008. $422 \mathrm{c}$.

12. Шиян Б. М. Підготовка вчителя фізичної культури третього тисячоліття. Концепція розвитку галузі фізичного виховання і спорту в Україні. Рівне. 2001. Вип. 2. С. 371-374.

\section{REFERENCES}

1. Azhyppo, O. Yu. (2013). Teoretyko-metodychni zasady pidhotovky maibutnikh uchyteliv fizychnoi kultury do profesiinoi diialnosti $v$ zahalnoosvitnikh navchalnykh zakladakh [Theoretical-methodical bases of preparation of future teachers of physical culture for professional work in secondary schools]. Extended abstract of Doctor's thesis. Kharkiv, 485p. [in Ukrainian].

2. Artemovych, O. I. (2004). Vplyv riznykh vydiv fizkulturno-sportyvnykh zaniat na riven fizychnoho zdorovia pidlitkiv [The effect of different types of sports and physical training on the physical health of adolescents]. Modern problems of physical education and sport pupils and students of Ukraine. Sumy: SumDPU, pp. 178-183. [in Ukrainian].

3. Hilova, I. (2007). Vprovadzhennia innovatsiinykh tekhnolohii ta yikh elementiv na urokakh fizychnoi kultury [The introduction of innovative technologies and their components in the lessons of physical culture]. Physical education in school, no 3. pp. 22-24. [in Ukrainian].

4. Driukov, V. O. (2007). Ratsionalnist sportyvnoi pidhotovky [The rationality of athletic training]. The Olympic arena, no. 11. pp. 6-8. [in Ukrainian].

5. Zakharina, Ye. A. (2012). Profesiina pidhotovka maibutnikh uchyteliv fizychnoi kultury do pozaklasnoi ta pozashkilnoi ozdorovcho-vykhovnoi roboty: teoriia ta metodyka: monohrafiia [Professional training of future teachers of physical culture to extracurricular and after-school recreational and educational work: theory and methodology]. Zaporozhye: CPU, 439 p. [in Ukrainian].

6. Masliuk, R. V. (2015). Profesiina pidhotovka maibutnikh uchyteliv fizychnoi kultury v systemi "pedahohichnyi koledzh - pedahohichnyi universytet" [Professional training of future teachers of physical culture in the system of "pedagogical College and pedagogical University”]. Candidate's thesis. Uman, 286 p. [in Ukrainian].

7. Maksymchuk, B. A. (2007). Pidhotovka maibutnikh uchyteliv pochatkovykh klasiv do orhanizatsii sportyvnomasovoi roboty [Training of future primary school teachers to the organization of sports-mass work]. Candidate's thesis. Vinnitsa, 176p. [in Ukrainian].

8. Onopriienko, O. V. (2009). Formuvannia bazovykh profesiinykh kompetentnostei maibutnoho vchytelia fizychnoi kultury u protsesi vyvchennia fakhovykh dystsyplin [The formation of the basic professional competence of future teacher of physical culture in the process of studying of special disciplines]. Extended abstract of candidate's thesis. Cherkassy, 20 p. [in Ukrainian].

9. Platonov, V. N. (2004). Sistema podgotovki sportsmenov $v$ olimpiyskom sporte. Obshchaya teoriya $i$ ee prakticheskie prilozheniya [The system of preparation of sportsmen in Olympic sport. The General theory and its practical applications]. Kyiv: Olympic literature, 808 p. [in Russian].

10. Shyian, B. M. (2001). Pidhotovka vchytelia fizychnoi kultury tretoho tysiacholittia [Training of teachers of physical culture of the third Millennium]. The concept of development a branch of physical 
training and sports in Ukraine, vol.2. Rivne, pp. 371374. [in Ukrainian].

11. Sushchenko, A. V. (2011). Rozvytok pedahohichnoi tvorchosti maibutnikh uchyteliv fizychnoho vykhovannia $\mathrm{v}$ khodi pedahohichnoi praktyky [The development of pedagogical creativity of future physical education teachers during teaching practice]. Pedagogy of formation of creative personality in higher and secondary schools. Zaporozhye, Vol.19. pp. 275-280. [in Ukrainian].

12. Tymoshenko, O. V. (2008). Optymizatsiia profesiinoi pidhotovky maibutnikh vchyteliv fizychnoi kultury: monohrafiia [Optimization of professional preparation of future teachers of physical culture: monograph.]. Kyiv: NPU im. M. P. Dragomanov, 422 p. [in Ukrainian].

Стаття надійшла до редакції 15.02.2018
УДК 378.146:004.4

DOI:

Юлія Корницька, кандидат педагогічних наук, доиент Національний технічний університет Украӥни “Київський політехнічний інститут імені Ігоря Сікорського"

\section{РОЛЬ ТА МІСЦЕ ТЕСТУВАННЯ В НАВЧАННІ ІНОЗЕМНИХ МОВ}

У статті розглядається потенціал тестування для організації об'єктивного та технологічного моніторингу якості іншомовної підготовки майбутніх фахівців технічного профілю. На основі теоретичного аналізу актуальних досліджень представлено узагальнений перелік переваг використання тестів та комп'ютерних тестів зокрема, визначено доиільність використання тестів на різних етапах навчання. Запропоновано базовий алгоритм складання комп'ютерного тесту. Наведено приклади можливих технічних рішень.

Ключові слова: контроль; тест; переваги; рівні засвоєння; алгоритм; тестова оболонка.

Jim. 9.

Yuliya Kornytska, Ph.D.(Pedagogy), Associate Professor National Technical University of Ukraine "Kyiv Ihor Sikorskiy Polytechnic Institute"

\section{THE ROLE AND PLACE OFTESTING IN THE FOREIGN LANGUAGE TEACHING PROCESS}

The paper is devoted to the analysis of the testing methods implementation in the process of developing foreign language competence. Nowadays, the foreign language is considered as a means of communication and an effective tool for advancement both personal and professional. In conditions of the education paradigm shift, the methodology of foreign language teaching experiences a variety of innovations aimed to bring it in accordance to the new framework. Improving the process of developing foreign language competence actualizes the questions of its quality control as a significant condition for its success. The peculiarities of the new curricula impose to use more flexible, rational and technological methods of assessment. On the basis of the theoretical analysis of the actual researches, the author outlines testing as the most appropriate one to provide efficient, impartial and systematic monitoring and assessment. Computer-aided testing is considered as the solution for enhancing above mentioned pros and making the process more technological with concomitant advantages. The paper presents the key advantages of testing in comparison to the traditional methods, benefits of computeraided testing. The author reasons the practicability of implementing test on the different stages of the acquiring process. Based on the results of actual researches and practical experience, the algorithm of developing computer test is described and some available technical solutions are offered with the detailed description of the one used by the author in practice. As the perspective vector for further investigation on the problem the author outlines stating and specifying pedagogical conditions for implementing computer-aided testing.

Keywords: a control; a test; advantages; an acquisition level; an algorithm; the test frame.

П остановка проблеми. Компетентністна парадигма сучасної вищої освіти актуалізує пошук нових рішень в методиці викладання іноземних мов. Однак, для забезпечення належної якості іншомовної підготовки важливим є не лише вдосконалення процесу розвитку іншомовної комунікативної компетентності, але й пошук адекватних форм його моніторингу. Своєчасна та об'єктивна інформація про хід навчального процесу,

(C) Ю. Корницька, 2018 проблемах та досягненнях студентів у оволодінні іншомовною комунікативною компетенцією $є$ необхідною умовою ефективного навчального процесу. Зважаючи на протиріччя між існуючими вимогами та обмеженою кількістю аудиторних годин особливої актуальності набуває пошук шляхів та способів оптимізації процесу навчання іноземних мов та використання нових гнучких, раціональних і технологічних методів контролю та самоконтролю. Оптимальним рішенням для 